\title{
LINGKUNGAN HIDUP DAN ALQURAN (STUDI DESKRIPTIF MULTI-PENDEKATAN AYAT-AYAT ALQURAN)
}

\author{
Yenni Rahman \\ STAI Darul Quran Payakumbuh, yenni.are06@gmail.com \\ Ihzan Nuzula \\ STAI Darul Quran Payakumbuh, ibsan_zamrigmail.com
}

\begin{tabular}{|c|c|c|}
\hline Diterima: 12 Juli 2018 & Direvisi : 25 Oktober 2018 & Diterbitkan: 30 Desember 2018 \\
\hline
\end{tabular}

\begin{abstract}
Humans can not be separated from the environment, the environment is very meaningful for the survival of humans and other living things. Environment as a system, a system consists of components that work regularly as a unit. Searching the Koran's terms of the environment, through two approaches, namely the substance approach and the language approach. Of the two approaches, seven words connote the environment in the Koran. The seven words are al-ardh, al-balad, al-qaryah, al-alamin, al-sama', al-biah, and jaww. Environmental preservation in the Koran is human being as part of the environment, humans as environmental users, and humans as holders of trust in maintaining the environment. The environmental preservation measures are to avoid environmental destruction, reduce lust, prioritize the afterlife than the world, approach political policies, realize the consequences of environmental destruction, maintain the cycle and availability of water, and increase garden and garden lands.
\end{abstract}

Keywords: Alquran, lingkungan, dan pelestarian

\begin{abstract}
Abstrak
Manusia tidak bisa terlepas dari yang namanya lingkungan bidup, lingkungan bidup sangat berarti bagi kelangsungan manusia dan makbluk bidup lainnya. Lingkungan sebagai suatu sistem, suatu sistem terdiri atas komponen-komponen yang bekerja secara teratur sebagai suatu kesatuan. Penelusuran term-term Alquran tentang lingkungan hidup, melalui dua pendekatan yaitu pendekatan subtansi dan pendekatan bahasa. Dari dua pendekatan tersebut didapatkan tujuh kata yang berkonotasi dengan lingkungan hidup dalam Alquran. Adapun tujuh kata tersebut adalah al-ardh, al-balad, al- qaryah, al-alamin, al-sama', al-biah, dan jaww. Pelestarian lingkungan bidup dalam Alquran yaitu manusia sebagai bagian dari lingkungan hidup, manusia sebagai pengguna lingkungan hidup, dan manusia sebagai pemegang amanah dalam memelihara lingkungan bidup. Adapun langkah pelestarian lingkungan bidup yaitu menghindari perusakan lingkungan, meredam hawa nafsu, memprioritaskan akbirat daripada dunia, pendekatan kibijakan politik, menyadari akibat dari perusakan lingkungan, menjaga siklus serta ketersediaan air, dan memperbanyak lahan kebun dan taman.
\end{abstract}

Kata kunci: Alquran, lingkungan, dan pelestarian

\section{PENDAHULUAN}

Manusia tidak bisa terlepas dari yang namanya lingkungan hidup, lingkungan hidup sangat berarti bagi kelangsungan manusia dan makhluk hidup lainnya. Lingkungan sebagai suatu sistem, suatu sistem terdiri atas komponen-komponen yang bekerja secara teratur sebagai suatu kesatuan. Atau seperangkat unsur yang secara teratur saling berkaitan sehingga membentuk suatu totalitas. Lingkungan terdiri atas unsur biotik (manusia, hewan, dan tumbuhan) dan abiotik (udara, air, 
tanah, iklim dan lainnya). Allah SWT berfirman dalam surat al-Hijr ayat 19-29, "Dan Kami telah menghamparkan bumi dan menjadikan padanya gunung-gunung dan Kami tumbubkan padanya segala sesuatu menurut ukuran. dan Kami telab menjadikan untukmu di bumi keperluankeperluan bidup, dan (kami menciptakan pula) makbluk-makbluk yang kamu sekali-kali bukan pemberi reqki kepadanya. Berdasarkan penjelasan diatas, manusia tidak bisa dipisahkan dari lingkungan dan sangat membutuhkan lingkungan untuk tempat hidup. Oleh sebab itu, agar untuk lebih jelasnya akan dibahas tentang lingkungan hidup dalam al-Quran.

Masalah lingkungan hidup pada saat sekarang sudah menjadi isu global karena menyangkut kepentingan umat manusia. $\mathrm{Hal}$ ini dibukti dengan adanya isu kerusakan lingkungan yang semakin parah. Diantara penyebabnya isu efek rumah kaca, lapisan ozon yang menipis, kenaikan suhu udara, dan mencairnya es di kutub. Khususnya negara Indonesia yang memiliki potensi alam yang sangat melimpah. Dengan potensi alam yang sedemikian melimpahnya telah membuat orang-orang berusaha untuk mengolah secara maksimal tanpa memikirkan prinsip pembangunan berkelanjutan. Peningkatan pengolahan sumber daya alam yang tidak terkendali akan menyebabkan munculnya kerusakan lingkungan. Dan keruskan alam akan i menjadi sumber bencana alam akibat ulah manusia sendiri.

Kerusakan alam atau lingkungan hidup sebagian besar adalah hasil perbuatan manusia. Karena manusia yang diberi tanggung jawab sebagai khalifah di bumi. Manusia mempunyai daya inisiatif dan kreatif, sedangkan makhluk-makhluk lainnya tidak memiikinya. Kebudayaan manusia makin lama makin maju sesuai dengan perkembangan dan kemajuan ilmu pengtahuan dan teknologi. Kerusakan lingkungan diperparah lagi dengan banyaknya kendaraan bermotor, dan pabrikpabrik yang menimbulkan pencemaran udara atau polusi. Pencemaran tersebut membahayakan keselamatan hidup manusia dan kehidupan sekelilingnya. Limbah-limbah pabrik sering kali dibuang seenaknya ke sungai yang akhirnya bermuara ke laut. Demikian pula kapal-kapal tanker yang membawa minyak sering mengalami kebocoran, sehinggga minyaknya tumpah ke laut. Akibatnya, air sungai dan laut beracun yang menyebabkan mati atau tercemarnya ikan dengan zat beracun.

Karena itu, dapat disimpulkan bahwa kerusakan yang terjadi saat ini merupakan akibat dari perbuatan manusia yang memilih jalan pintas untuk dapat mengeksploitasi lingkungannya secara besar-besaran sehingga mengakibatkan kerusakan lingkungan. Untuk lebih jelasnya agar kembali kepada ajaran Alqur'an dalam pengelolaan lingkungan. Agar dapat menjalankan ajaran Islam dengan benar tentang lingkungan hidup.

Artikel ini mencoba menjelaskan nilai-nilai lingkungan hidup dan ekologi yang terkandung dalam ayat-ayat Alquran.

\section{METODE}

Dalam penulisan artikel ini, digunakan metode tematik (maudhu'i). Metode maudbu'i berguna untuk memperoleh sebuah kesimpulan dan pemahaman yang komperehensif. Metode maudhu'i ini diambil dari metode al-Farmawi. Metode tersebut digunakan dalam mencari ayat secara maudhu'i, yaitu mengumpulkan ayat-ayat yang terkait dengan satu topik dan pemahamannya yang disertai dengan penjelasan, pengungkapan dan penafsiran tentang masalah tertentu. Dalam memahami kata lingkungan hidup dalam Alquran dilakukan dengan dua pendekatan yaitu pendekatan subtansi dan pendekatan bahasa.

\section{PENGERTIAN LINGKUNGAN HIDUP}

Istilah lingkungan, lingkungan alam dan lingkungan hidup telah dipakai untuk 
maksud yang sama, yaitu lingkungan hidup. Dalam bahasa inggris lingkungan atau lingkungan hidup disebut dengan kata environment. Environment berarti kondisi fisik, kimiawi, dan keadaan makhluk hidup yang ada disekitar organism. ${ }^{1}$

Lingkungan hidup adalah kesatuan ruang dengan semua benda, daya, keadaan, dan makhluk hidup, termasuk manusia dan perilakunya yang mempengaruhi kehidupan dan kesejahteraan manusia serta makhluk hidup lainnya; lingkungan di luar suatu organisme yang terdiri atas organisme hidup seperti tumbuhan, hewan dan manusia dan organism tidak hidup atau benda mati yaitu air, udara dan lainnya. ${ }^{2}$

Berdasarkan Undang-Undang tentang ketentuan pokok pengelolaan lingkungan hidup (undang-undang nomor 4 tahun 1982 dan undang-undang nomor 23 tahun 1997, lingkungan hidup adalah kesatuan dengan semua, daya, keadaan, dan makhluk hidup termasuk di dalamnya manusia dan perilakunya yang mempengaruhi kelangsungan perikehidupan dan kesejahteraaan manusia serta makhluk hidup lainnya. ${ }^{3}$

Definisi lainnya, lingkungan hidup adalah jumlah dan kondisi yang ada dalam ruang yang kita tempati dan juga yang mempengaruhi hidup kita. ${ }^{4}$ Berdasarkan defenisi di atas memberikan gambaran bahwa lingkungan hidup terdiri dari ruang, benda dan energi dengan segala keadaannya, serta makhluk hidup dengan segala jenis dan tingkatannya.

TERM LINGKUNGAN HIDUP DALAM ALQURAN

\footnotetext{
${ }^{1}$ Michel Allaby, Dictionary of the Environment, ( London: The Mac Millan Press Ltd, 1979), hal. 80

${ }^{2}$ Kamus Besar Bahasa Indonesia/ Tim

Penyusun Kamus Pusat Bahasa, (Jakarta: Balai Pustaka, 2002), Ed. 3, Cet. 2, Hal. 675

${ }^{3}$ Jur Andi Hamzah, Penegakan Hukum

Lingkungan Hidup, ( Jakarta: Sinar Grafika, 2005), hal. 1

${ }^{4}$ Otto Surwanto, Lingkungan Hidup dan

Pembangunan, (Jakarta: Djambatan, 2004), hal. 30
}

Penelusuran term-term Alquran tentang lingkungan hidup, melalui dua pendekatan yaitu pendekatan subtansi dan pendekatan bahasa.

Pendekatan Bahasa maksudnya pendekatan yang mengunakan jalur kamus yang melacak istilah bahasa arab yang bermakna lingkungan hidup. Dalam penelusuran kamus ditemukan enam kata yang bermakna lingkungan hidup, tetapi hanya dua kata yang sesuai dengan Alquran dan berhubungan dengan lingkungan hidup yaitu kata biab dan jaww.

Untuk menelusuri term Alquran yang mengandung pengertian lingkungan hidup, dapat dimulai melalui pengertian lingkungan hidup itu sendiri. Berdasarkan kalimat yang menunjukkan arti ruang, kawasan atau tempat kehidupan makhluk hidup. Ruang adalah tempat bagi makhluk hidup untuk menempatkan diri. Bagi manusia dan makhluk lainnya ruang kehidupan adalah hamparan permukaan bumi, baik daratan maupun lautan. Penelusuran juga dapat dilakukan melalui, pemahaman terhadap unsur lingkungan lainnya, yakni makhluk hidup dan benda mati.

Berdasarkan penelusuran melalui pendekatan subtansi, ditemukan lima term Alquran yang bermakna lingkungan hidup yaitu al-ardh (bumi, tanah), al-samak (udara, ruang bebas permukaan bumi, langit), al'alamin (seluruh makhluk), al-balad dan alqaryah (kota, negeri, kampung).

Dari dua pendekatan di atas, didapatkan tujuh kata yang berkonotasi dengan lingkungan hidup dalam Alquran.

Al-Ardh

Bermakna tanah atau lapisan tanah pada surat al-Qashash ayat 81;

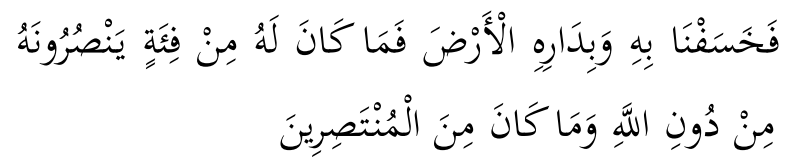

Maka Kami benamkanlah Karun beserta rumahnya ke dalam bumi. Maka tidak ada baginya suatu 
golonganpun yang menolongnya terhadap azab Allah. dan Tiadalah ia termasuk orang-orang (yang dapat) membela (dirinya).

Bermakna hamparan atau permukaan bumi sebagai tempat hidup dalam surat alAnkabut ayat 56,

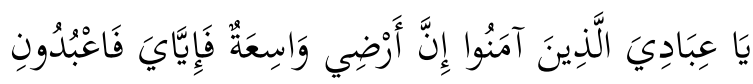

Hai hamba-hamba-Ku yang beriman, sesunggubnya bumi-Ku luas, Maka sembablab aku saja.

Bermakna negeri atau Negara dalam surat as-Syu'ara ayat 35 ,

$$
\text { يُرِيدُ أَنْ يُخْرِجَكُمْ مِنْ أَرْضِكُمْ بِسِحْرِهِ فَمَاذَا تَأْمُرُونَ }
$$

Ia bendak mengusir kamu dari negerimu sendiri dengan sibirmya; Maka karena itu apakah yang kamu anjurkan?"

Bermakna tanah milik atau lahan pertanian dalam surat al-Ahzab ayat 27,

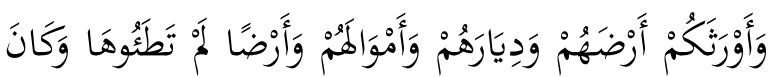

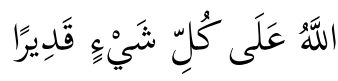

Dan dia mewariskan kepada kamu tanah-tanah, rumah-rumah dan harta benda mereka, dan (begitu pula) tanah yang belum kamu injak dan adalah Allah Maba Kuasa terbadap segala sesuatu.

\section{Al-Balad}

Kata al- balad dalam Alquran terdapat 20 kali dengan bentuk balad, baldan, bilad dan baldatan. Salah satunya terdapat pada surat alFurqan ayat 49 ,

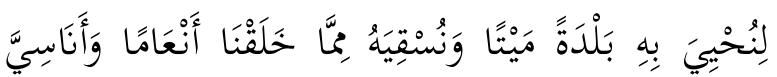

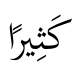

Agar Kami menghidupkan dengan air itu negeri (tanah) yang mati, dan agar Kami memberi minum dengan air itu sebagian besar dari makbluk. Kami, binatang-binatang ternak dan manusia yang banyak.

\section{Al-Oaryah}

Kata al-Qaryah muncul di dalam Alquran sebanyak 55 kali, dalam bentuk qaryah, qaryatukum, qaryatina, qaryataini dan al-qura.
Seperti yang tertera dalam Surat alBaqarah ayat 58 ,

وَإِذْ قُلْنَا اذْحُلُوا هَذَهِ الْقَرَيَةَ فَكُلُوا مِنْهَا حَيْثُ شِيْتُمْ

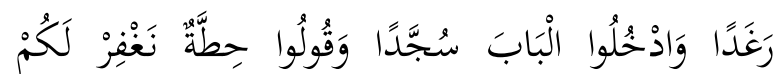
خَطَايَاكُمْ وَسَنَزِيدُ الْهُحْسِنِينَ

Dan (ingatlah), ketika Kami berfirman: "Masuklah kamu ke negeri ini (Baitul Maqdis), dan makanlah dari hasil buminya, yang banyak lagi enak dimana yang kamu sukai, dan masukilah pintu gerbangnya sambil bersujud, dan Katakanlab: "Bebaskanlah Kami dari dosa", niscaya kami ampuni kesalahankesalabanmu, dan kelak kami akan menambah (pemberian Kami) kepada orang-orang yang berbuat baik".

Al-'Alamin

Kata al-'Alamin merupakan bentuk jamak dari kata 'alam. Di dalam Alquran kata al-'alamin dalam bentuk gabungan kata muncul sebanyak 74 kali yang tersebar dalam 31 surat. $^{5}$

Susunan rabb al-alamin, muncul sebanyak 42 kali. Salah satunya dalam surat alFatihah ayat 2 ,

$$
\text { الْحْمْدُ لِلَّهِ رَبِ الْعَالَمِينَ }
$$

Segala puji bagi Allah, Tuban semesta alam.

Alhamdu (segala puji). memuji orang adalah karena perbuatannya yang baik yang dikerjakannya dengan kemauan sendiri. Maka memuji Allah berrati: menyanjung-Nya karena perbuatannya yang baik. lain halnya dengan syukur yang berarti: mengakui keutamaan seseorang terhadap nikmat yang diberikannya. kita menghadapkan segala puji bagi Allah ialah karena Allah sumber dari segala kebaikan yang patut dipuji.

Rabb (tuhan) berarti: Tuhan yang ditaati yang memiliki, mendidik dan Memelihara. Lafal Rabb tidak dapat dipakai selain untuk Tuhan, kecuali kalau ada

${ }^{5}$ Sirajudin Zar, KOnsep Penciptaan Alam Dalam Pemikiran Islam, Sains dan al-Quran, ( Jakarta: PT. Raja Grafindo, 1997), Cet. Ke II, hal. 19 
sambungannya, seperti rabbul bait (tuan rumah). 'Alamiin (semesta alam): semua yang diciptakan Tuhan yang terdiri dari berbagai jenis dan macam, seperti: alam manusia, alam hewan, alam tumbuh-tumbuhan, benda-benda mati dan sebagainya. Allah Pencipta semua alam-alam itu.

Susunan li al-'alamin, muncul sebanyak 13 kali. Salah satunya pada surat Ali Imran ayat 96 ,

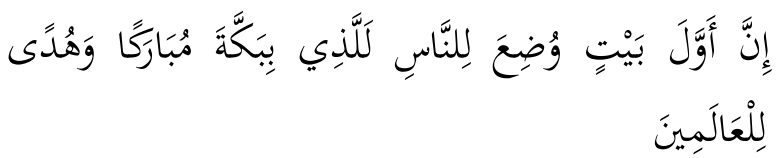

Sesunggubnya rumah yang mula-mula dibangun untuk (tempat beribadat) manusia, ialah Baitullah yang di Bakeah (Mekah) yang diberkabi dan menjadi petunjuk bagi semua manusia.

Susunan 'ala al-'alamin, muncul 8 kali. Salah satunya dalam surat al-Baqarah ayat 47,

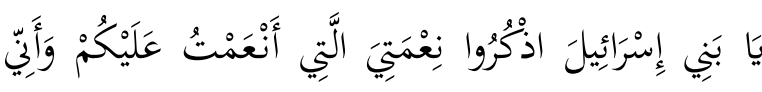

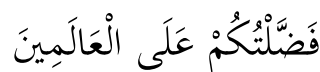

Hai Bani Israil, ingatlah akan nikmat-Ku yang telah aku anugerabkan kepadamu dan (ingatlah pula) bahwasanya aku telah melebihkan kamu atas segala umat.

Susunan fi al-'alamin, muncul satu kali pada surat as-shaffat ayat 79 ,

$$
\text { سَالَامُ عَلَى نُوحِح فِي الْعَالَمِينَ }
$$

"Kesejabteraan dilimpabkan atas Nub di seluruh alam".

Susunan min al-'alamin, muncul 6 kali. Salah satunya dalam surat al-Maidah ayat 20,

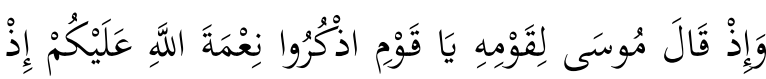

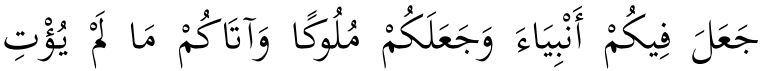

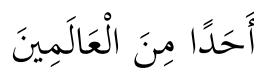

Dan (ingatlah) ketika Musa berkata kepada kaumnya: "Hai kaumku, ingatlah nikmat Allah atasmu ketika Dia mengangkat Nabi Nabi diantaramu, dan dijadikan-Nya kamu orang-orang merdeka, dan diberikan-Nya kepadamu apa yang belum pernab diberikan-Nya kepada seorangpun diantara umat-umat yang lain".

Susunan 'an al-'alamin, muncul 2 kali. Salah satunya pada surat al-Hijr ayat 70 ,

$$
\text { قَالُوا أَوَلَزْ نَنْهَكَكَ عَنْ الْعَالَمِينَ }
$$

Mereka berkata: "Dan Bukankah Kami telab melarangmu dari (melindungi) manusia?"

Mereka ingin berbuat homosexual dengan tamu-tamu itu dan mereka memang telah pernah mengancam Luth, agar tidak menghalangi mereka daripada berbuat demikian.

Susunan nisa' al-'alamin pada surat Ali Imran ayat 42 ,

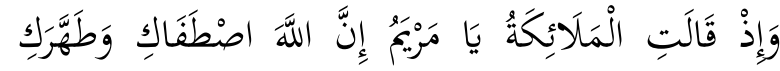
وَاصْطَفَاكِ عَلَى نِسَاٍِِ الْعَالَمِينَ Dan (ingatlab) ketika Malaikat (Jibril) berkata: "Hai Maryam, Sesunggubnya Allah telah memilih kamu, mensucikan kamu dan melebibkan kamu atas segala wanita di dunia (yang semasa dengan kamu).

Susunan shudur al-'alamin pada surat alAnkabut ayat 10,

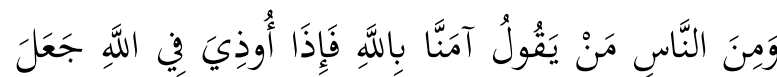

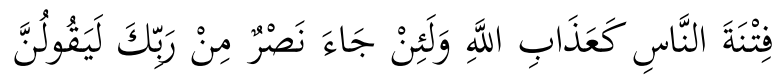

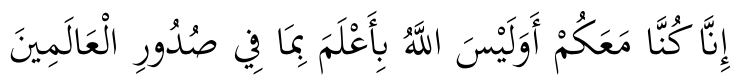
Dan di antara manusia ada orang yang berkata: "Kami beriman kepada Allab", Maka apabila ia disakiti (karena ia beriman) kepada Allah, ia menganggap fitnah manusia itu sebagai azab Allah. dan sungguh jika datang pertolongan dari Tuhanmu, mereka pasti akan berkata: "Sesunggubnya Kami adalab besertamu". Bukankah Allab lebih mengetahui apa yang ada dalam dada semua manusia?

Maksudnya: orang itu takut kepada penganiayaan-penganiayaan manusia terhadapnya karena imannya, seperti takutnya kepada azab Allah, karena itu ditinggalkannya imannya itu.

$\underline{\text { Al-Sama' }}$ 
Kata al-sama' (jamak: samawat). Di dalam Alquran muncul 310 kali, dalam bentuk tunggal 120 kali dan dalam bentuk jamak 190 kali.

Al-sama' berarti langit, salah satunya pada surat al-Baqarah ayat 22,

الَّذِي جَعَلَ لَكُمُ الْأَرْضَ فِرَاشًَا وَالسَّمَاءَ بِنَاءً وَأَنْزَلَ مِنَ

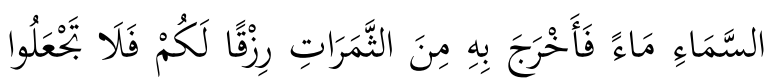

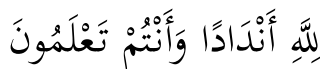

Dialah yang menjadikan bumi sebagai hamparan bagimu dan langit sebagai atap, dan Dia menurunkan air (bujan) dari langit, lalu Dia menghasilkan dengan bujan itu segala buab-buahan sebagai ręki untukmu; karena itu janganlah kamu Mengadakan sekutusekutu bagi Allah, Padahal kamu mengetabui.

Al-sama' berarti jagad raya, salah satunya pada surat al-Furqan ayat 61 ,

$$
\begin{aligned}
& \text { تَبَارَكَ الَّذِي جَعَلَ فِي السَّمَاءِ بُرُوجَا وَجَعَلَ فِيهَا سِرَاجَا } \\
& \text { وَقََمَرًا مُنِيرً }
\end{aligned}
$$

Maha suci Allah yang menjadikan di langit gugusangugusan bintang dan Dia menjadikan juga padanya matahari dan bulan yang bercabaya.

\section{Al-Bi'ah}

Kata biah berasal dari kata baa, yabiu, bi atan yang berarti kembali, menempati wilayah, ruang kehidupan dan lingkungan. Ada beberapa konotasi makna bi ah di dalam Alquran, sebagai berikut.

Bermakna lagi atau berulang pada surat al-Baqarah ayat 61 ,

وَإِذْ قُلْتُمْ يَا مُوسَى لَنْ نَصْبرَ عَلَى طَعَامٍ وَاحٍٍِ فَادْعُ لَنَا

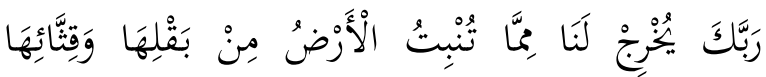

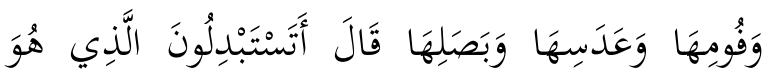

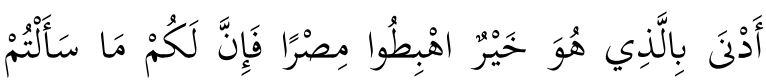

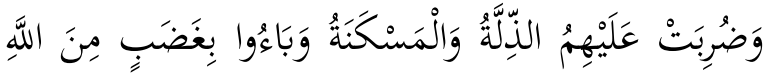

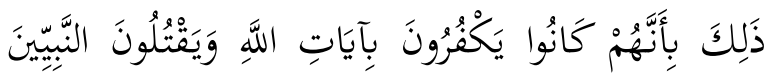

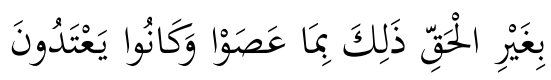

Dan (ingatlab), ketika kamu berkata: "Hai Musa, Kami tidak bisa sabar (tahan) dengan satu macam makanan saja. sebab itu mobonkanlah untuk Kami kepada Tuhanmu, agar Dia mengeluarkan bagi Kami dari apa yang ditumbubkan bumi, Yaitu sayurmayurnya, ketimunnya, bawang putibnya, kacang adasnya, dan bawang merahnya". Musa berkata: "Maukah kamu mengambil yang rendah sebagai pengganti yang lebih baik? Pergilah kamu ke suatu kota, pasti kamu memperoleb apa yang kamu minta". lalu ditimpabkanlah kepada mereka nista dan kehinaan, serta mereka mendapat kemurkaan dari Allah. hal itu (terjadi) karena mereka selalu mengingkari ayat-ayat Allah dan membunub Para Nabi yang memang tidak dibenarkan. demikian itu (terjadi) karena mereka selalu berbuat durbaka dan melampani batas.

Bermakna memancing atau mengundang pada surat Ali Imran ayat 162, أَفَمَنْ انَّبَعَ رِضْوَانَ اللَِّ كَمَنْ بَاءَ بِسَخَطِ مِنَ اللَّهِ وَمَأْوَاهُ

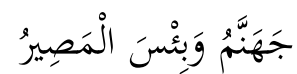

Apakah orang yang mengikuti keridhaan Allah sama dengan orang yang kembali membawa kemurkaan (yang besar) dari Allah dan tempatnya adalah Jahannam? dan Itulah seburuk-buruk tempat kembali.

Bermakna pulang kembali pada surat al-Maidah ayat 29,

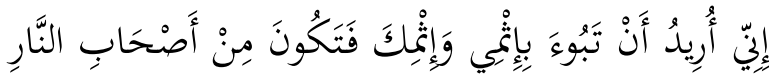

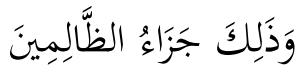

"Sesunggubnya aku ingin agar kamu kembali dengan (membawa) dosa (membunub)ku dan dosamu sendiri, Maka kamu akan menjadi penghuni neraka, dan yang demikian Itulah pembalasan bagi orang-orang yang ralim."

Bermakna tempat, kedudukan pada surat Ali Imran ayat 121,

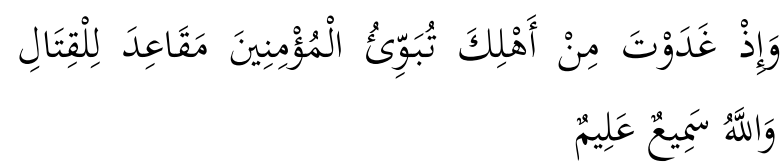

Dan (ingatlah), ketika kamu berangkat pada pagi hari dari (rumah) keluargamu akan menempatkan Para mukmin pada beberapa tempat untuk 
berperang. dan Allah Maha mendengar lagi Maha mengetahui,

Peristiwa ini terjadi pada perang Uhud yang menurut ahli sejarah terjadi pada tahun ke $3 \mathrm{H}$.

Jaww

Pada surat an-Nahl ayat 79 ,

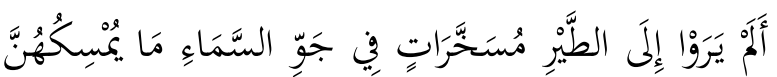

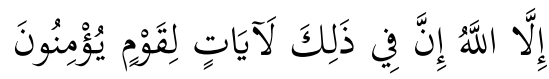

Tidakekah mereka memperhatikan burung-burung yang dimudabkan terbang diangkasa bebas. tidak ada yang menahannya selain daripada Allah. Sesunggubnya pada yang demikian itu benar-benar terdapat tanda-tanda (kebesaran Tuhan) bagi orangorang yang beriman.

Quraish Shihab memaknai ayat di atas dengan "tidaklah mereka kaum musyrikin dan para pendurbaka melihat, yakni memperbatikan bagaimana burung-burung yang ditundukean oleh Allah, sehingga mudah baginya untuk terbang melayang di angkasa bebas". ${ }^{6}$ Berdasarkan makna ayat, maka kata jawn merupakan salah satu term lingkungan hidup dalam Alquran yaitu lingkungan udara.

\section{PELESTARIAN LINGKUNGAN HIDUP DALAM ALQURAN}

Dalam hal ini Alquran menjelaskan peran dan tanggung jawab manusia dalam melestarikan lingkungan serta langkah-langkah yang semestinya ditempuh dalam upaya pelestarian lingkungan hidup.

Manusia sebagai pelestari lingkungan hidup

Dalam upaya pelestarian lingkungan hidup, pertama Alquran menjelaskan kedudukan dan fungsi manusia ditengah lingkungan hidup itu. Dengan menjelaskan hakiakat keberadaan manusia dibumi, menjadijelas tujuan, tugas dan tanggung jawab manusia terhadap makhluk-makhluk lainnya.

${ }^{6}$ Quraish Shihab, Tafsir al-Misbah: Pesan, Kesan dan Keserasian, (Jakarta: Lentera Hati, 2000), hal. 310
Berdasarkan pembacaan terhadap ayatayat Alquran yang berkaitan dengan term-term lingkungan hidup, maka hakikatnya keberadaan manusia di bumi sekurangnya ada tiga, yaitu pertama sebagai bagian dari lingkungan hidup, kedua sebagai pengguna lingkungan hidup dan ketiga sebagai pemegang amanah pemelihara lingkungan hidup.

Manusia sebagai bagian dari lingkungan hidup

Dasarnya terdapat dalam surat alAn'am ayat 38,

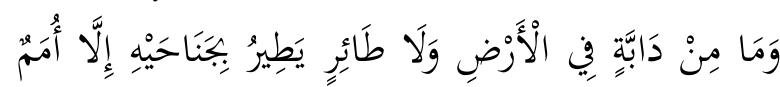

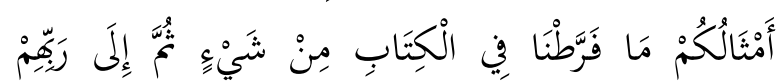
يُحْنَرَوَْنَ

Dan Tiadalah binatang-binatang yang ada di bumi dan burung-burung yang terbang dengan kedua sayapnya, melainkan umat (juga) seperti kamu. Tiadalah Kami alpakan sesuatupun dalam Al-Kitab, kemudian kepada Tubanlah mereka dibimpunkan.

Sebagian mufassirin menafsirkan AlKitab itu dengan Lauhul mahfudz dengan arti bahwa nasib semua makhluk itu sudah dituliskan (ditetapkan) dalam Lauhul mahfudz. dan ada pula yang menafsirkannya dengan Alquran dengan arti: dalam Alquran itu telah ada pokok-pokok agama, norma-norma, hukum-hukum, hikmah-hikmah dan pimpinan untuk kebahagiaan manusia di dunia dan akhirat, dan kebahagiaan makhluk pada umumnya.

Manusia sebagai pengguna lingkungan hidup

Segala sesuatu yang ada dibumi adalah fasilitas yang sengaja disediakan Allah untuk keperluan hidup manusia. Sebagaimana terdapat dalam surat al-Baqarah ayat 29,

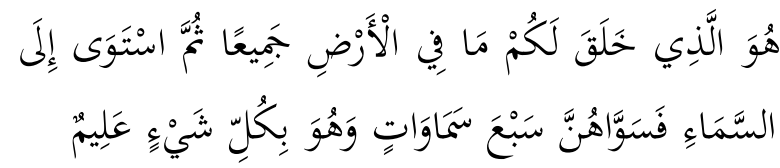

Dia-lah Allah, yang menjadikan segala yang ada di bumi untuk kamu dan Dia berkehendak (menciptakan) langit, lalu dijadikan-Nya tujub langit. dan Dia Maha mengetahui segala sesuatu. 
Kesan yang kuat dari ayat tersebut adalah bahwa bumi dengan segala isinya memang diciptakan Allah untuk dimanfaatkan oleh manusia bagi kelanjutan dan kenyamanan hidupnya. Kedudukan manusia sebagai pengguna lingkungan hidup dalah semata-mata atas izin dan kepemurahan Allah. Manusia tidak dapat menguasai makhluk lain tanpa izin dan pertolongan Allah. Dialah yang memerintahkan makhluk lain untuk tunduk dan dapat dimaanfaatkan oleh manusia.

Manusia sebagai pemegang amanah memelihara lingkungan hidup

Sebagai makhluk yang telah diberi kelebihan akal oleh Allah, maka peran manusia maka peran manusia terhadap lingkungan sangat dominan. Manusia dapat menjadi penyebab utam agangguan keseimbangan ekologis. Sebaliknya manusia juga dapat menjadi factor yang efektif bagi pemulihan dan penjaga keseimbangan lingkungan hidup dengan kemampuan yang ia miliki. Sebagaimana terdapat dalam surat al-Ahzab ayat 72 ,

إِنَّا عَرَضْنَا الْأْمَانَةَ عَلَى السَّمَاوَاتِ وَالْأَرْضِ وَالْجِبَالِ

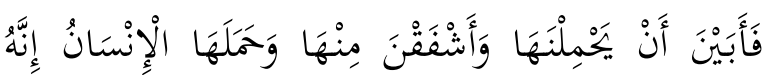

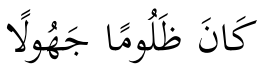

Sesunggubnya Kami telab mengemukakan amanat kepada langit, bumi dan gunung-gunung, Maka semuanya enggan untuk memikul amanat itu dan mereka khawatir akan mengkbianatinya, dan dipikullah amanat itu oleh manusia. Sesunggubnya manusia itu Amat zalim dan Amat bodoh,

\section{LANGKAH DALAM PELESTARIAN LINGKUNGAN HIDUP}

Menghindari perusakan lingkungan

Term pengrusakan dala Alquran diungkapkan dengan kalimat "ifsad". Kata ifsad dan derivasinya muncul dalam Alquran sebanyak 50 kali dalam 47 ayat di 23 surat. Jika kita membaca dengan teliti, justru perusakan lingkungan hidup merupakan salah satu bentuk perusakan yang telah diwanti-wanti oleh Alquran. Sebagaimana firman-Nya yang terdapat dalam surat al-A'raf ayat 56,

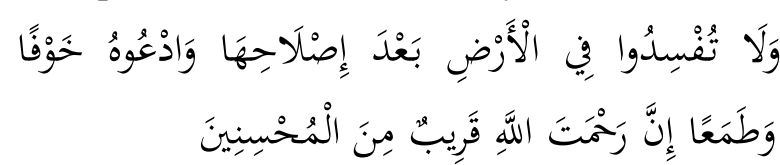

Dan janganlah kamu membuat kerusakan di muka bumi, sesudab (Allab) memperbaikinya dan Berdoalab kepada-Nya dengan rasa takut (tidak akan diterima) dan harapan (akan dikabulkan). Sesunggubnya rahmat Allah Amat dekat kepada orang-orang yang berbuat baik.

Menurut Ibnu Katsir, maksud ayat tersebut adalah Allah melarang perbuatan yang menimbulkan kerusakan dimuka bumi dan hal-hal yang membahayakan kelestariannya sesudah diperbaiki. Karena sesungguhnya apabila segala sesuatu berjalan dengan kelestariannya, kemudian terjadi kerusakan padanya hal tersebut akan membahayakan semua makhluk Allah SWT.

\section{Meredam hawa nafsu}

Sudah jelas bahwa salah satu akar penyebab kerusakan lingkungan hidup adalah prilaku individu. Bentuk perilaku negative tersebut antara lain tamak, boros dan tidak bertanggung jawab. Alquran menjelaskan bahwa terdapat hubungan yang nyata antara perilaku individu dengan tingkat kerusakan dimuka bumi. Sebagaiman firman Allah yang terdapat dalam surat al-Mukminun ayat 71 ,
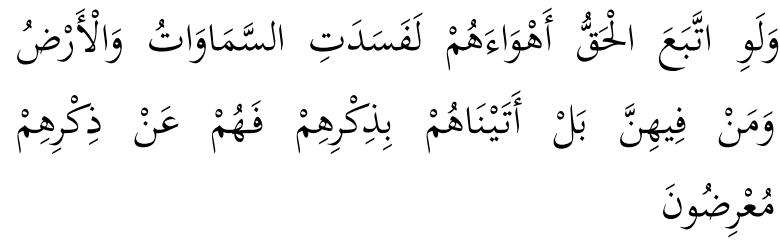

Andaikata kebenaran itu menuruti hawa nafsu mereka, pasti binasalah langit dan bumi ini, dan semua yang ada di dalamnya. sebenarnya Kami telab mendatangkan kepada mereka kebanggaan (Al Quran) mereka tetapi mereka berpaling dari kebanggaan itu.

Al-Maraghi memahami makna al-Haq adalah Allah SWT, maka beliau menyatakan :" 
sekiranya ia membolebkan kezaliman dan meninggalkan keadilan, niscaya manusia akan kacau balau, sekiranya ia membolebkan permusuban, perampokan harta dan orang yang lemah menjadi mangsa orang yang kuat, niscaya keamanan dan keteraturan tidak akan stabil...sekiranya ia membolehkan perzinaa, niscayaketurunan akan rusak... Dan seterusnya, masih banyak kerusakan lainnya.

\section{Memprioritaskan akhirat daripada dunia}

Di samping mengendalikan nafsu dari ketamakan, boros dan tidak bertanggung jawab. Alquran memberikan visi kehidupan yang jelas bagi manusia, yakni mengarahkan pandangan kepada kehidupan akhirat sebagai prioritas. Menjadikan kehidupan dunia sebagai sarana untuk mencapai prioritas itu. Bukan dunia ini yang menjadi tujuan hidup, sebagaimana firman Allah yang terdapat dalam surat al-Qashash ayat 77,

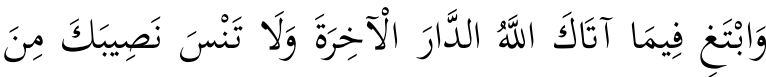

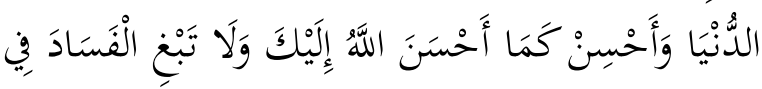

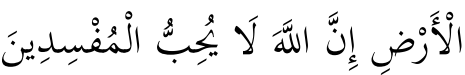

Dan carilah pada apa yang telab dianugerabkan Allah kepadamu (kebahagiaan) negeri akhirat, dan janganlah kamu melupakan bahagianmu dari (kenikmatan) duniawi dan berbuat baiklah (kepada orang lain) sebagaimana Allah telab berbuat baik, kepadamu, dan janganlah kamu berbuat kerusakan di (muka) bumi. Sesunggubnya Allah tidak menyukai orang-orang yang berbuat kerusakan.

Berdasarkan pemahaman ayat di atas, menjadi jelas bahwa visi kehidupan yang berorientasi akhirat akan membuat manusia berhati-hati dalam tindakannya. Sepanjang hayat mereka akan selalu menjauhkan diri dari perbuatan-perbuatan yang merusak, termasuk merusak lingkungan hidup dan sebaliknya senantiasa berbuat ihsan. Maksud ayat tersebut

${ }^{7}$ Ahmad Mustafa Al-Maraghi, Tafsir al-Maraghi, (Mesir: Mustafa al-babi al-Halabi), jilid. 18, hal. 76 juga sewjalan dengan firman Allah dalam surat al-Qashash ayat 83,

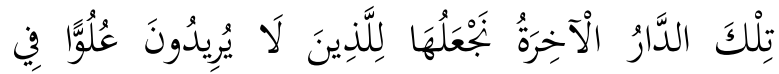

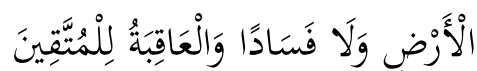

Negeri akbirat itu, Kami jadikan untuk orang-orang yang tidak ingin menyombongkan diri dan berbuat kerusakan di (muka) bumi. dan kesudahan (yang baik) itu adalah bagi orang-orang yang bertakwa.

\section{Pendekatan kebijakan politik}

Allah melarang bentuk pengrusakan lingkungan hidup. Kerusakan lingkungan hidup, salah satunya disebabkan oleh perang dan konflik antar Negara, baik secara langsung maupun tidak langsung.

Kehancuran dan kerusakan merupakan hasil yang harus dituai jika hal itu terjadi. Karena perang dalam berbagai skalanya sudah identik dengan kehancuran. Hal ini sebagaimana diisyaratkan dalam firman Allah surat al-Naml ayat 34,

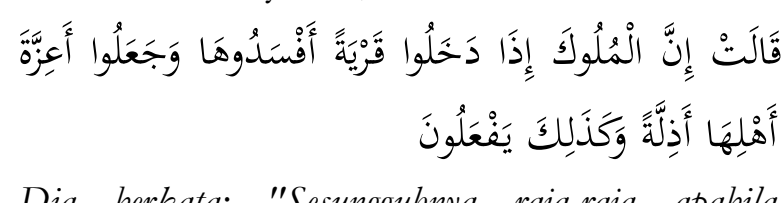

Dia berkata: "Sesunggubnya raja-raja apabila memasuki suatu negeri, niscaya mereka membinasakannya, dan menjadikan penduduknya yang mulia Jadi hina dan demikian pulalah yang akan mereka perbuat.

Berdasarkan pemahaman dari ayat ini, kiranya memadai dijadikan dasar untuk menyimpulkan bahwa salah satu upaya buntuk mencegah perusakan lingkungan hidup, sedapatnya menghindari peperangan dan konflik dalam segala bentuk dan skalanya. Pengalaman sejarah maupun fakta yang terbentang dihadapan kita menegaskan efek buruk peperangan dan konflik terhadap kelestarian lingkungan.

\section{Menyadari akibat dari perusakan lingkungan}

Pendekatan ini dimaksudkan untuk menjelaskan hubungan logis antara berbagai kerugian langsung maupun tidak langsung 
yang akan dialami manusia akibat kerusakan lingkungan dengan cara hidup dan perilaku mereka sendiri dalam berintegrasi dengan alam. Sebagaimana firmna Allah yang terdapat dalam surat ar-Rum ayat 41,
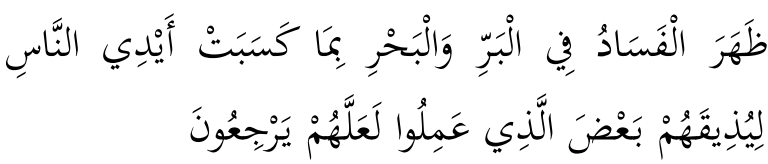

Telah nampak kerusakan di darat dan di laut disebabkan karena perbuatan tangan manusi, supaya Allab merasakan kepada mereka sebahagian dari (akibat) perbuatan mereka, agar mereka kembali (ke jalan yang benar).

Tantawi Jauhari, yang dikenal sebagai mufassir dengan pendekatan ilmiah, dalam aljawahir menghubungkan kerusakan di darat dan laut dengan peperangan dan pertempuran. Yakni kerusakan dalam bentuk kekacauan karena perang dan berlalu lintasnya peralatan tempur seperti tank, kendaraan lapis baja, pesawat tempur, kapal perang, kapal selam dan lainnya. ${ }^{8}$

Menjaga siklus dan ketersediaan air

Air meruopakan sumber kehidupan. Di mana air dsitu ada kehidupan. Pengaturannya ditetapkan melalui mekanisme sunnah berupa penetapan sifat-sifat yang khas. Sifat air yang cair, memilki keyegangan permukaan yang kuat, dapat mendidih, membeku dan berubah bentuk menjadi padat, cair dan gas. Informasi Alquran tentang fungsi dan manajemen air, terdapat dalam surat alBaqarah ayat 22,

اللَّنِي جَعَل لَكُمُ الْأَرَْْ فِرَاشًا وَالسَّمَاءَ بِنَاءً وَأَنْزَلَ مِنَ

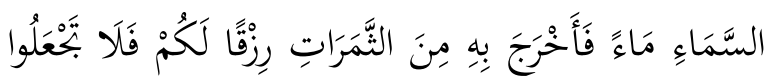

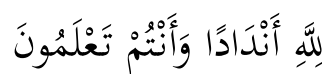

Dialah yang menjadikan bumi sebagai hamparan bagimu dan langit sebagai atap, dan Dia menurunkan air (bujan) dari langit, lalu Dia menghasilkan dengan bujan itu segala buah-buaban sebagai reqki untukmu;

${ }^{8}$ Tantawi Jauhari, Al-Jawabir fi Tafsir al-Quran al-Karim, Dar Al Fikr, Juz 15, hal. 77 karena itu janganlah kamu Mengadakan sekutusekutu bagi Allah, padahal kamu mengetahui.

Sejalan dengan ayat di atas, Allah juga berfirman dalan surat al-Furqan ayat 49, "Agar Kami menghidupkan dengan air itu negeri (tanab) yang mati, dan agar Kami memberi minum dengan air itu sebagian besar dari makbluk. Kami, binatangbinatang ternak dan manusia yang banyak.".

Dalam ayat ini, Allah menjelaskan dua fungsio penting air bagi kehidupan. Pertama, menyuburkan atau menghidupkan tanah yang tandius sehingga bias ditumbuhi oleh berbagai macam tanaman. Kedua, sebagai minuman bagi makhluk hidup yakni untuk manusia, hewan dan tunmbuhan.

\section{Memperbanyak kebun dan taman}

Taman dan kebun yang subur merupakan salah satu komponen lingkungan hidup yang penting. Pemandangan yang hijau dan asri adalah gambaran lingkungan hidup yang senantiasa didambakan oleh orang-orang. Hal ini sebagai mana yang digambarkan Allah pada surat as-Saba ayat 15 ,

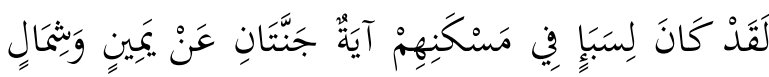

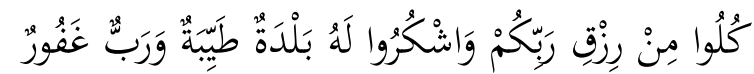
Sesunggubnya bagi kaum Saba' ada tanda (kekuasaan Tuban) di tempat kediaman mereka Yaitu dua buah kebun di sebelab kanan dan di sebelab kiri. (kepada mereka dikatakan): "Makanlab olebmu dari rezki yang (dianugerabkan) Tubanmu dan bersyukurlah kamu kepada-Nya. (Negerimu) adalab negeri yang baik dan (Tubanmu) adalab Tuban yang Maha Pengampun".

Meskipun secara umum konteks ayat ini adalah pengajaran sejarah masa lalu, tapi disamping itu juga boleh dipahami tentang gambaran suatu negeri yang baik dan makmur itu antara lain memilki taman dan kebun sebagaimana yang ada dnegeri Saba'. Sorga juga digambarkan oleh Alquran dengan sebutan jannah (taman). Yang menciptakan jenis-jenis tanaman dan menumbuhkannya memang Allah, akan tetapi manusia dapat 
memilih dan mengatur jenis dan dapat menanamnya.

Maka salah satu usaha yang dapat dilakukan untuk mengembangkan lingkungan hidup adalah dengan menanam sebanyakbanyaknya dan mengatur sedemikian rupa jenis tanaman yang akan dikembangkan dan dikelola dan lokasi yang tepat untuk penanaman tersebut.

\section{KESIMPULAN}

Menelusuri tema lingkungan hidup dalam Alquran, dapat melalui dua pendekatan yaitu pendekatan bahasa dan pendekatan subtansi. Dari pendekatan bahas didapatkan dua kata yang berhubungan dengan lingkungan hidup yaitu biah dan jaw, sedangkan dari pendekatan subtansi didapatkan lima kata yang maknanya berhubungan dengan subtansi lingkungan hidup berdasarkan pengertian bahasa Indonesia. Berdasarkan pembahsan di atas, dapat dipahami bahwa Alquran memberikan perhatian yang besar terhadap lingkungan hidup dibuktikan dengan banyaknya ayat Alquran yang membahas tentang lingkungan hidup. 


\section{DAFTAR KEPUSTAKAAN}

Michel Allaby, Dictionary of the Environment, London: The Mac Millan Press Ltd.

Kamus Besar Bahasa Indonesia/ Tim Penyusun Kamus Pusat Bahasa, Jakarta: Balai Pustaka, 2002, Ed. 3, Cet. 2.

Jur Andi Hamzah, Penegakan Hukum Lingkungan Hidup, Jakarta: Sinar Grafika, 2005

Otto Surwanto, Lingkungan Hidup dan Pembangunan, Jakarta: Djambatan, 2004

Sirajudin Zar, KOnsep Penciptaan Alam Dalam Pemikiran Islam, Sains dan Alquran, Jakarta: PT. Raja Grafindo, 1997, Cet. Ke II

Quraish Shihab, Tafsir al-Misbah: Pesan, Kesan dan Keserasian, Jakarta: Lentera Hati, 2000 